\title{
Review of optimum temperature, humidity, and vapour pressure deficit for microclimate evaluation and control in greenhouse cultivation of tomato: a review
}

\author{
Redmond Ramin Shamshiri, ${ }^{1,2}$, James W. Jones ${ }^{2}$, Kelly R. Thorp $^{3}$, Desa Ahmad ${ }^{1}$, Hasfalina Che Man', \\ and Sima Taheri ${ }^{4}$

\begin{abstract}
${ }^{1}$ Smart Farming Technology Research Center, Department of Biological and Agricultural Engineering, Faculty of Engineering, Universiti Putra Malaysia, 43400, Serdang, Selangor, Malaysia

${ }^{2}$ Department of Agricultural and Biological Engineering, University of Florida, Gainesville, Florida, USA

${ }^{3}$ United States Department of Agriculture, Agricultural Research Service, 21881 N Cardon Ln, Maricopa, AZ 85138, USA

${ }^{4}$ Department of Crop Science, Faculty of Agriculture, Universiti Putra Malaysia, 43400 Serdang, Selangor, Malaysia
\end{abstract}

Received July 13, 2017; accepted February 16, 2018

\begin{abstract}
Greenhouse technology is a flexible solution for sustainable year-round cultivation of Tomato (Lycopersicon esculentum Mill), particularly in regions with adverse climate conditions or limited land and resources. Accurate knowledge about plant requirements at different growth stages, and under various light conditions, can contribute to the design of adaptive control strategies for a more cost-effective and competitive production. In this context, different scientific publications have recommended different values of microclimate parameters at different tomato growth stages. This paper provides a detailed summary of optimal, marginal and failure air and root-zone temperatures, relative humidity and vapour pressure deficit for successful greenhouse cultivation of tomato. Graphical representations of the membership function model to define the optimality degrees of these three parameters are included with a view to determining how close the greenhouse microclimate is to the optimal condition. Several production constraints have also been discussed to highlight the short and long-term effects of adverse microclimate conditions on the quality and yield of tomato, which are associated with interactions between suboptimal parameters, greenhouse environment and growth responses.

Keywords: optimal air temperature, relative humidity, vapour pressure deficit, greenhouse, tomato, membership functions
\end{abstract}

\section{INTRODUCTION}

Sustainable greenhouse production requires the integration of information and management strategies, as well as excellent understanding of the influencing microclimate parameters. In this regard, the proper understanding of the variations in greenhouse microclimate, in conjunction with the requirements of tomato at different growth stages, merit special attention. Tomato (Lycopersicon esculentum) is one of the most widely-grown greenhouse vegetables in the world (Viuda-Martos et al., 2014), and it is highly demanded by fresh market and processing industries. It favours moderate to warm climate with additional light improving fruit development and yield. Moreover, tomato can grow well in soil, organic substrates, soilless mixes, perlite, sand or hydroponic. Different techniques and methods of determinant and indeterminate varieties of tomato planting under open-field and greenhouse conditions are available in the textbooks of Cherie (2010), Hochmuth and Hochmuth (2012), Jones (2013), and Van Ploeg and Heuvelink (2005). A comprehensive review of tomato by-products with respect to human health benefits and applications is available in the work of Viuda-Martos et al. (2014).

A greenhouse is defined as a covered structure that can provide plants with optimally-controlled microclimate growth conditions. In cold climates, there is a great advantage in having a controlled environment, whereas for moderate and tropical regions, it provides an extension of the production season and protection against diseases and insects. The greenhouse environment encompasses climatic and nutritional elements, along with structural and mechanical conditions. If properly managed, it can significantly 
increase fruit quality and yields. Since the costs associated with greenhouse cultivation are generally higher, due to the initial investments in the structure, equipment and energy, the understanding of optimal microclimate parameters for automatic control is necessary to achieve high yield at low expenses and to keep the production efficient. The success of system analyses in greenhouse automation and control relies on the effective use of information. Reducing the excessive energy required for greenhouse heating and cooling, especially in regions with adverse climate conditions, is a major concern in terms of maintaining a competitive power in the market. For instance, fruit yield and quality of tomato are directly affected by microclimate parameters. As tomato plants are sensitive to both high and low air temperatures, greenhouse cultivation in the regions displaying such climate conditions that are not adequately close to the base requirements will involve additional risks and production costs. Therefore, an important sustainability challenge lies in shifting from energy-consuming, to energy-neutral greenhouses. This can be done by accurately assessing short and long-term risks associated with the interactions between climate conditions, greenhouse environment and growth responses. In other words, knowing how far from optimal a greenhouse microclimate can be, without sacrificing production quality and yield, would contribute to the creation of a proper automation level for energy management and environmental impact reduction, as well as to the maximisation of the use of natural resources (i.e., to successfully shifting from greenhouses with advanced climate control systems, to those that maximise efficient use of shading and natural ventilation).

The main environmental factors affecting greenhouse tomato include air and root-zone temperatures, relative humidity $(R H)$, light conditions $(L)$, disease and insect intervention, as well as carbon dioxide (Jones, 2013). The adequate management of these parameters, in order to achieve maximum returns with minimum energy inputs, has a direct impact on tomato growth development and plays a crucial role in preventing crop stress. This paper reviews the optimal and marginal temperature levels, $R H$ values and vapour pressure deficit (VPD) for the greenhouse cultivation of tomato at different growth stages and under different light conditions. These parameters are known for influencing plant evapotranspiration and have significant effects on growth and physiological cycles. A sufficiently detailed summary of literature addressing adverse microclimate effects on tomato fruit quality and yield, as well as cultivation constraints with suboptimal values, is provided. Such information will contribute to knowledge-based decision-support systems for efficient energy management in greenhouse climate control and cost-effective year-round cultivation. It can also be used in the design of more flexible micro-climate control strategies through better understanding of the control parameters and their interactions with tomato productivity and yield. Plant responses to other influencing factors such as carbon dioxide, nutrient solution, cultivar variety and grower skill are covered in the textbook of Morison and Morecroft (2006).

\section{GROWTH STAGES OF TOMATO}

The optimum levels of microclimate for the best greenhouse cultivation of tomato depend on different growth stages and light conditions. The five growth stages of tomato are described by Jones (2013) and García et al. (2011) as germination and early growth with initial leaves (between 25 and 35 days), vegetative period (20 to 25 days), flowering (20 to 30 days), early fruiting (20 to 30 days), and mature fruiting (15 to 20 days). The exact days within each stage depend on the varieties and other environmental factors such as air temperature, light condition, soil conditions and nutrients. Moreover, some varieties have been hybridized to specific climate or might be more sun tolerant, which makes their fruit production time shorter. The average duration to reach the mature fruiting stage (from transplanting) for most greenhouse tomato varieties, depending on the cultivar, different maturity levels and ripeness, is between 65 to 100 days. The estimated time from planting to marketable maturity is between 50 and 65 days for an early variety, and between 85 and 95 days for a late variety (Jones, 2013). Another source (García et al., 2011) reported two growth periods of 133 days and 126 days in two different experiments. However, a minimum of 75 days from transplanting was reported to be required to reach the first harvest for most cultivated tomatoes (Jones, 2013). Medium early varieties like 'Champion' and 'Mountain Spring' have average production of about 65 days. Main Crop varieties, including 'Brandywine', 'Celebrity', 'Better Boy', 'Fantastic,' 'Burpee's Big Girl', 'Sioux', 'Mountain Pride' and 'Supersonic' are considered to be the tastiest and of best quality within 70 and 80 days. Furthermore, extralarge tomato varieties such as 'Beefsteak', 'Shuntukski Velikan' and 'Neves Azorean Red' have an average production time of about 80 to 85 days. Thus, the number of days from seeding to harvesting of the first fruits, according to Jones (2013), varies from 45 days to over 100 days, depending on the maturity level of the cultivar. The five growth stages of tomato are illustrated graphically in Fig. 1, along with different fruit maturity levels and ripeness. It should be noted that tomatoes are harvested two to four times a week, and only when they have reached the mature green stage (vine-ripe), as they start to ripen.

\section{OPTIMUM AIR AND ROOT-ZONE TEMPERATURE}

Maintaining an optimum average daily air temperature is crucial for pollen development and also for maintaining a good anther in tomato flowers. Different references have reported different values of air temperature and humidity to be optimal for each specific growth stage. For example, Sato et al. (2000) recommended as optimal, air temperature 


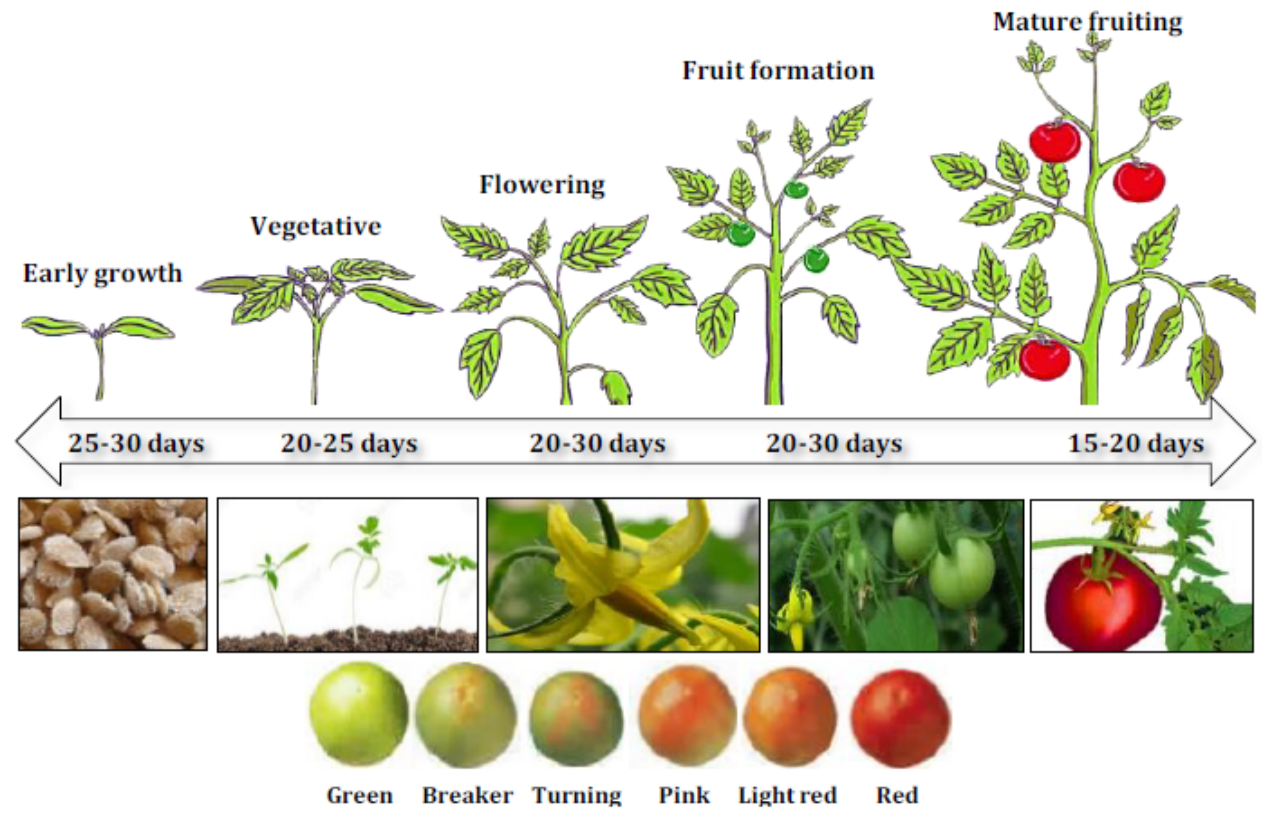

Fig. 1. Demonstration of the five growth stages of tomato, and the different levels of fruit ripeness.

of $22^{\circ} \mathrm{C}$ for leaf/truss development, $22-26^{\circ} \mathrm{C}$ for fruit addition and $22-25^{\circ} \mathrm{C}$ for fruit growth and fruit-set. Greenhouse crops are mostly warm-season crops which are adapted to optimal air temperatures between $17-27^{\circ} \mathrm{C}$, with the lower and upper marginal temperature of 10 and $35^{\circ} \mathrm{C}$ (Kittas et al., 2005). In general, values between 18.3 and $32.2^{\circ} \mathrm{C}$ are considered to be optimal air temperatures for tomato during the entire growing season (Cherie, 2010; Hochmuth and Hochmuth, 2012). Fundamental requirements regarding the cultivation environment of tomato are considered by Baudoin et al. (2013) as an average ambient air temperature in the range of $17-28^{\circ} \mathrm{C}$ in coastal areas and $17-22^{\circ} \mathrm{C}$ in inland areas far from the sea (with the minimum and maximum tolerable values of 12 and $32^{\circ} \mathrm{C}$, and the minimum global radiation of $2.34 \mathrm{kWh} \mathrm{m}^{-2} \mathrm{day}^{-1}$ ). This difference is due to the fact that the daily temperature fluctuations in inland areas are around $20^{\circ} \mathrm{C}$, and approximately $10^{\circ} \mathrm{C}$ higher than those in coastal areas (Baudoin et al., 2013). For proper physiological functioning, tomato requires thermal periodicity (an average temperature difference between day and night) between 5 and $7^{\circ} \mathrm{C}$, with at least $500-550 \mathrm{~h}$ of day light in the usual three-month growing season (an average of $6 \mathrm{~h} \mathrm{light} \mathrm{day}^{-1}$ ) (Baudoin et al., 2013). Under hot and humid tropical climate conditions, Ajwang and Tantau (2005) reported that while air temperature can rise to $38^{\circ} \mathrm{C}$, the temperature inside a greenhouse without a climate controller may be $20-30^{\circ} \mathrm{C}$ higher than outside (Kittas et al., 2005). The same source considered temperatures above $26^{\circ} \mathrm{C}$ as failure values and suggested that values exceeding $25^{\circ} \mathrm{C}$ would most likely reduce tomato production. Kittas et al. (2005) also suggested that the maximum greenhouse air temperature should not exceed $30-35^{\circ} \mathrm{C}$. Under the hot climate conditions of Mediterranean summer months, Harel et al. (2014) thought that an average daily temperature of up to $26^{\circ} \mathrm{C}$ could be achieved in a greenhouse shelter when using evaporative cooling such as low pressure fogging systems. The optimal air temperature for tomato germination is recommended to be at $25^{\circ} \mathrm{C}$, by Van Ploeg and Heuvelink (2005), followed by the minimum night time temperature of $18^{\circ} \mathrm{C}$ and the daily maximum of $27^{\circ} \mathrm{C}$ for seedling growth. Jones (2013) recommended that the ideal air temperature for seedling growth should be between 16 and $18.5^{\circ} \mathrm{C}$. Moreover, Adams et al. (2001) claimed that the rate of fruit addition (fruit-set, from pollination) had an optimum air temperature at or lower than $26^{\circ} \mathrm{C}$ and progressively failed with temperature reaching $32^{\circ} \mathrm{C}$. Finally, air temperatures of $18.5-26.5^{\circ} \mathrm{C}$ with day and night temperatures, respectively, between $21-29.5^{\circ} \mathrm{C}$ and $18.5-21^{\circ} \mathrm{C}$ were reported to be optimal (Jones 2013).

Studies have shown that canopy (leaf) temperature may be far more important in plant growth. The combination of $R H$ and the plant transpiration rate determine the canopy temperature. The optimal range for air temperature inside the canopy is recommended to be between 20 and $22^{\circ} \mathrm{C}$ (Jones, 2013). Results of simulation with an adaptive management framework (Shamshiri et al., 2017a) and the TOMGRO model (Jones et al., 1999) are consistent with these findings, showing that for hot and humid tropical climates, the lower and upper marginal borders of air temperature for germination is 16 and $30^{\circ} \mathrm{C}$, for maximum yield 20 and $25^{\circ} \mathrm{C}$, and for growth development 12 and $30^{\circ} \mathrm{C}$. It is suggested that the lowest tolerable and optimum air temperature should be, respectively, kept at 7 and $22^{\circ} \mathrm{C}$ for the rate of leaf appearance, the rate of truss appearance and the rate of progress (Adams et al., 2001). In addition, the rate of fruit development and maturation has a base 
temperature of $5.7^{\circ} \mathrm{C}$ and an optimum temperature of $26^{\circ} \mathrm{C}$, while the rate of individual fruit growth has its optimum at $22-25^{\circ} \mathrm{C}$ (Adams et al., 2001). Finally, according to Duchowski and Brazaitytë (2001), leaf photosynthesis of tomato has a base air temperature of $6-8^{\circ} \mathrm{C}$, with the optimum established at $30^{\circ} \mathrm{C}$.

Root-zone temperature also affects tomato growth, especially in the processes of shoot formation and flowering. However, interaction may exist with air temperature, solar radiation and length of day light. Jones (2013) put forward that a root-zone temperature of $27^{\circ} \mathrm{C}$ would be ideal for tomato, while, Li et al. (2015) observed that a root-zone temperature of $23^{\circ} \mathrm{C}$ during summer had the least drought stress effect on tomato between treatments in the range of 22 and $33^{\circ} \mathrm{C}$. Furthermore, Ntatsi et al. (2014) reported that, as compared to an optimal root-zone temperature of $25^{\circ} \mathrm{C}$, leaf area expansion of tomato, as well as shoot elongation and plant biomass were decreased at a suboptimal root-zone temperature of $15^{\circ} \mathrm{C}$. Reports indicate that in cold regions, under optimal greenhouse air temperature, root-zone heating first improves the root growth, and then influences the shoot growth (Kawasaki et al., 2014; Shishido and Kumakura, 1994; Tindall et al., 1990). A comprehensive review of the effects of root-zone temperature on plant growth is available in the works of Vogelezang (1993) and Li et al. (2015). Tomato yield was also found to be significantly positively correlated with soil moisture content (Chen et al., 2015). The optimum soil temperature for tomato germination, at which seedlings are likely to emerge between 5 and 7 days, is $29.5^{\circ} \mathrm{C}$ (Olson et al., 2012). The minimum required temperature for seed germination is $8-10^{\circ} \mathrm{C}$, with the optimum range between $16-29.5^{\circ} \mathrm{C}$, and the maximum tolerable temperature of $35^{\circ} \mathrm{C}$ (Jones, 2013). The time to germination declines from 14 to 5 days with a temperature increase from 15.5 to $29.5^{\circ} \mathrm{C}$, and it then grows to 9 at $35^{\circ} \mathrm{C}$ (Olson et al., 2012). In addition, the number of days to seedling emergence decrease from 43 to 6 with an increase in soil temperature from 10 to $30^{\circ} \mathrm{C}$, and it then grows to 9 at temperatures above $35^{\circ} \mathrm{C}$ (Jones, 2013). Furthermore, the ideal soil temperature, depending on the light intensity and the phase of growth and development, is reported in the range of 13 to $25^{\circ} \mathrm{C}$ by Mahajan and Singh (2006). Baudoin et al. (2013) held that during night and cloud hours, the optimal soil temperature for the development stage, flowering stage and harvesting stage was, respectively, between $13-14,15-16$, and $20-22^{\circ} \mathrm{C}$, while these values during sun hours were 17-20, 19-22, and $23-25^{\circ} \mathrm{C}$, respectively. They, therefore, recommended that soil temperature should be larger than $14^{\circ} \mathrm{C}$, when ambient $R H$ is between 70 and $90 \%$. Depending on the stage of development, a summary of reviewed literature that suggested optimal, marginal, and failure temperature for greenhouse cultivation of tomato is provided Table 1.

\section{OPTIMUM HUMIDITY AND VAPOUR PRESSURE DEFICIT}

Total greenhouse humidity is the result of condensation on the covering, vapour losses from ventilation and the balance between plants transpiration and soil evapotranspiration. It is expressed in scientific literature as absolute humidity $\left(\mathrm{g} \mathrm{m}^{-3}\right)$, specific humidity ( $\mathrm{g}$ water $\mathrm{kg}^{-1}$ air) or relative humidity (percentage); the latter, however, being more common. For most greenhouse tomato varieties, relative humidity range between $60-90 \%$ is considered appropriate by ASABE (2015) standards. Moreover, the optimal range of relative humidity during the entire growth stages of tomato is suggested to be between $50-70 \%$. Studies also show that Tomato pollination is significantly enhanced when $R H$ is around $60 \%$ (Harel et al., 2014). It should be underlined that plants exposed to higher temperature require higher humidity (Kittas et al., 2005). This is related to the plant transpiration. Thus, in a greenhouse condition with air around plant leaves too hot and humid, the transpiration at the leaf surface will be ineffectual and the root and stem system may not be able to supply adequate water to the leaves. Cooling is, therefore, required to reduce these stresses. In regions with cold climate, $R H$ is generally low due to lower transpiration and higher levels of condensation.

Humidity alone does not provide any information about plant transpiration, and it cannot be used as a good indicator of the vapour pressure stress on plants. The main parameter for controlling plant water uptake in the greenhouse environment, which, in turn, affects other physiological process (i.e., pollination, growth and yield), is the air water vapour pressure deficit. It is the driving force for water movement between roots and leaves. VPD is the difference between saturation vapour pressure $\left(e_{s}\right)$ and the actual vapour pressure $\left(e_{d}\right)$. It is directly related to transpiration and affects the quality and yield of tomato fruits. The saturation water vapour pressure increases exponentially with an increase in air temperature. Estimation of plant evapotranspiration $(E T)$ or water loss to the atmosphere depends on $V P D$. This parameter can also be used as an indication to determine how close a closed-field environment is to saturation. According to Zolnier et al. (2000), VPD is capable of more accurately reflecting how the plant feels by taking into account both the measurements of temperature and $R H$. Another important application of $V P D$ estimation is to evaluate the condensation potential of a greenhouse crop and to identify when it is likely to happen. Reports also indicate that plant radiation use efficiency is related to $V P D$ (Stockle and Kiniry, 1990). Several ET models that rely on VPD have been presented in the work of Jensen et al. (1990), along with a detailed discussion of its computation methods. Given $T\left({ }^{\circ} \mathrm{C}\right)$ and $R H(\%), V P D$ can be computed from the following equation in $\mathrm{kPa}$. A comprehensive discussion on the comparison between other computations 
Table 1. Summary of reviewed literature suggesting optimal, marginal, and failure temperature for greenhouse cultivation of tomato. $\mathrm{T}_{\mathrm{A}}$ - air temperature, $\mathrm{T}_{\mathrm{r}}$ - root-zone temperature, $\mathrm{T}_{\mathrm{S}}$ - soil temperature, $\mathrm{F}$ - failure, $\mathrm{M}$ - marginal, Op - optimal

\begin{tabular}{|c|c|c|c|c|}
\hline Zone & Range $\left({ }^{\circ} \mathrm{C}\right)$ & Level & Description of growth stage & Reference \\
\hline $\mathrm{T}_{\mathrm{A}}$ & $<5.7$ & $\mathrm{~F}$ & during fruit development and maturation & (Adams et al., 2001) \\
\hline $\mathrm{T}_{\mathrm{A}}$ & {$[6,8]$} & F & base temperature for leaf photosynthesis & $\begin{array}{l}\text { (Duchowski and Brazaitytë, } \\
\text { 2001) }\end{array}$ \\
\hline $\mathrm{T}_{\mathrm{A}}$ & $<7$ & $\mathrm{~F}$ & $\begin{array}{l}\text { during leaf appearance, rate of truss appearance, and rate of } \\
\text { progress }\end{array}$ & (Adams et al., 2001) \\
\hline $\mathrm{T}_{\mathrm{A}}$ & $=8.5$ & $\mathrm{~F}$ & was used in TOMGRO model & (Jones et al., 1999) \\
\hline $\mathrm{T}_{\mathrm{S}}$ & {$[8,10]$} & M & minimum required soil temperature for seed germination & (Jones, 2013) \\
\hline $\mathrm{T}_{\mathrm{A}}$ & $<12$ or $>30$ & M & growth development (in warm climates) & (Jain, 2012) \\
\hline $\mathrm{T}_{\mathrm{S}}$ & {$[13,14]$} & Op & $\begin{array}{l}\text { soil temperature, development before flowering, (night and } \\
\text { cloud) }\end{array}$ & (Popovski, 1997) \\
\hline $\mathrm{T}_{\mathrm{S}}$ & $=14$ & M & minimum recommended for most greenhouse crops & (Baudoin et al., 2013) \\
\hline $\mathrm{T}_{\mathrm{r}}$ & $<15$ & $\mathrm{~F}$ & $\begin{array}{l}\text { decreases leaf area expansion, shoot elongation and plant } \\
\text { biomass }\end{array}$ & (Ntatsi et al., 2014) \\
\hline $\mathrm{T}_{\mathrm{S}}$ & {$[15,16]$} & Op & soil temperature, flowering (night and cloud) & (Popovski, 1997) \\
\hline $\mathrm{T}_{\mathrm{S}}$ & {$[15.5,29.5]$} & Op & $\begin{array}{l}\text { soil temperature for germination, the time to germination } \\
\text { declines from } 14 \text { to } 5 \text { days with increasing of temperature from } \\
15.5 \text { to } 29.5^{\circ} \mathrm{C}\end{array}$ & (Olson et al., 2012) \\
\hline $\mathrm{T}_{\mathrm{A}}$ & {$[16,18.5]$} & Op & for seedling growth & (Jones, 2013) \\
\hline $\mathrm{T}_{\mathrm{A}}$ & $<16$ or $>30$ & M & for germination (in warm climates) & (Jain, 2012) \\
\hline $\mathrm{T}_{\mathrm{S}}$ & {$[16,29.5]$} & Op & soil temperature for seed germination & (Jones, 2013) \\
\hline $\mathrm{T}_{\mathrm{A}}$ & {$[17,19]$} & Op & for full harvest (night) & (Omafra, 2005) \\
\hline $\mathrm{T}_{\mathrm{S}}$ & {$[17,20]$} & Op & soil temperature, development before flowering, sun & (Popovski, 1997) \\
\hline $\mathrm{T}_{\mathrm{A}}$ & {$[17,22]$} & Op & inland areas far from the sea & (Baudoin et al., 2013) \\
\hline $\mathrm{T}_{\mathrm{A}}$ & {$[17,27]$} & Op & for all growth stages & (Kittas et al., 2005) \\
\hline $\mathrm{T}_{\mathrm{A}}$ & {$[17,28]$} & Op & in coastal areas & (Baudoin et al., 2013) \\
\hline $\mathrm{T}_{\mathrm{A}}$ & $<18$ or $>27$ & M & $\begin{array}{l}\text { minimum night time and maximum day time for seedling } \\
\text { growth }\end{array}$ & $\begin{array}{l}\text { (Van Ploeg and Heuvelink } \\
\text { 2005) }\end{array}$ \\
\hline $\mathrm{T}_{\mathrm{A}}$ & {$[18.3,32.2]$} & Op & for all growth stages & $\begin{array}{l}\text { (Hochmuth and Hochmuth } \\
\text { 2012; Cherie, 2010) }\end{array}$ \\
\hline $\mathrm{T}_{\mathrm{A}}$ & {$[18.5,21]$} & Op & for all growth stages during night time & (Jones, 2013) \\
\hline $\mathrm{T}_{\mathrm{A}}$ & {$[18.5,26.5]$} & Op & $\begin{array}{l}\text { general recommendation for all growth stages and light } \\
\text { conditions }\end{array}$ & (Jones, 2013) \\
\hline $\mathrm{T}_{\mathrm{A}}$ & $=19$ & Op & for mature fruit, initiation of harvesting (day and night) & (Omafra, 2005) \\
\hline $\mathrm{T}_{\mathrm{A}}$ & {$[19,21]$} & Op & for plant raising (day and night) & (Omafra, 2005) \\
\hline $\mathrm{T}_{\mathrm{S}}$ & {$[19,22]$} & Op & soil temperature, flowering, sun & (Popovski, 1997) \\
\hline $\mathrm{T}_{\mathrm{A}}$ & {$[20,22]$} & Op & $\begin{array}{l}\text { for canopy temperature (light condition NA), for full harvest } \\
\text { (daylight) }\end{array}$ & (Jones, 2013; Omafra, 2005) \\
\hline $\mathrm{T}_{\mathrm{S}}$ & {$[20-22$} & Op & soil temperature, harvesting, (night and cloud) & (Popovski, 1997) \\
\hline $\mathrm{T}_{\mathrm{A}}$ & $<20$ or $>25$ & M & harvesting stage (in warm climates) & (Jain, 2012) \\
\hline $\mathrm{T}_{\mathrm{A}}$ & {$[21,29.5]$} & Op & for all growth stages during day time & (Jones, 2013) \\
\hline $\mathrm{T}_{\mathrm{A}}$ & $=22$ & Op & $\begin{array}{l}\text { for leaf and truss development, for rate of leaf appearance, rate } \\
\text { of truss appearance, and rate of progress }\end{array}$ & $\begin{array}{l}\text { (Sato et al., 2000; Adamset al., } \\
\text { 2001) }\end{array}$ \\
\hline $\mathrm{T}_{\mathrm{A}}$ & {$[22,25]$} & Op & $\begin{array}{l}\text { for fruit growth and fruit-set, rate of individual fruit growth will } \\
\text { be optimum }\end{array}$ & $\begin{array}{l}\text { (Adams et al., 2001; Sato et al., } \\
\text { 2000) }\end{array}$ \\
\hline $\mathrm{T}_{\mathrm{A}}$ & {$[22,26]$} & Op & for fruit addition & (Sato et al., 2000) \\
\hline
\end{tabular}


Table 1. Continuation

\begin{tabular}{|c|c|c|c|c|}
\hline Zone & Range $\left({ }^{\circ} \mathrm{C}\right)$ & Level & Description of growth stage & Reference \\
\hline $\mathrm{T}_{\mathrm{r}}$ & $=23$ & Op & during summer for least drought stress & (Li et al., 2015) \\
\hline $\mathrm{T}_{\mathrm{S}}$ & {$[23,25]$} & Op & soil temperature, harvesting, sun & (Popovski, 1997) \\
\hline $\mathrm{T}_{\mathrm{A}}$ & $=24$ & Op & for transplanting (day and night) & (Omafra, 2005) \\
\hline $\mathrm{T}_{\mathrm{A}}$ & $=24.4$ & M & $\begin{array}{l}\text { used in TOMGRO model as minimum as critical daytime } \\
\text { temperature, fruit growth was reduced when daytime } \\
\text { temperature average exceeded this value }\end{array}$ & (Jones et al., 1999) \\
\hline $\mathrm{T}_{\mathrm{A}}$ & $=25$ & Op & for germination (day and night) & $\begin{array}{l}\text { (Van Ploeg and Heuvelink, } \\
\text { 2005; Omafra, 2005) }\end{array}$ \\
\hline $\mathrm{T}_{\mathrm{r}}$ & $=25$ & Op & $\begin{array}{l}\text { for optimized leaf area expansion, shoot elongation and plant } \\
\text { biomass }\end{array}$ & (Ntatsi et al., 2014) \\
\hline $\mathrm{T}_{\mathrm{A}}$ & {$[25,26]$} & M & will likely reduce tomato production & (Kittas et al., 2005) \\
\hline $\mathrm{T}_{\mathrm{A}}$ & $=26$ & Op & $\begin{array}{l}\text { for best rate of fruit addition (fruit-set, from pollination), fruit } \\
\text { development and maturation }\end{array}$ & (Adams et al., 2001) \\
\hline $\mathrm{T}_{\mathrm{A}}$ & $=26$ & M & $\begin{array}{l}\text { fruit growth was found to reduce sharply with increasing of } \\
\text { mean daytime temperature above this value due to fruit abortion }\end{array}$ & (Jones et al., 1991) \\
\hline $\mathrm{T}_{\mathrm{r}}$ & $=27$ & Op & NO Information available & (Vermeulen et al., 2012) \\
\hline Ts & $=29.5$ & Op & seedlings will emerge between 5 and 7 days & (Olson et al., 2012) \\
\hline $\mathrm{T}_{\mathrm{A}}$ & $=30$ & Op & for leaf photosynthesis & $\begin{array}{l}\text { (Duchowski and Brazaitytë } \\
\text { 2001) }\end{array}$ \\
\hline $\mathrm{T}_{\mathrm{S}}$ & $=30$ & Op & $\begin{array}{l}\text { number of days to seedling emergence decrease from } 43 \text { to } 6 \\
\text { with increasing of } \mathrm{T}_{\mathrm{s}} \text { from } 10 \text { to } 30^{\circ} \mathrm{C}\end{array}$ & (Jones et al., 1999) \\
\hline $\mathrm{T}_{\mathrm{A}}$ & $>30$ & $\mathrm{~F}$ & NA & (Kittas et al., 2005) \\
\hline $\mathrm{T}_{\mathrm{A}}$ & $\geq 32$ & $\mathrm{~F}$ & fruit-set progressively fails after this temperature & (Adams et al., 2001) \\
\hline $\mathrm{T}_{\mathrm{S}}$ & $\geq 35$ & $\mathrm{~F}$ & $\begin{array}{l}\text { maximum tolerable soil temperature for seed germination, the } \\
\text { time to germination increase from } 5 \text { days to } 9 \text { days }\end{array}$ & (Jones, 2013; Olson et al., 2012) \\
\hline $\mathrm{T}_{\mathrm{S}}$ & $\geq 35$ & M & number of days to seedling emergence increase from 6 to 9 days & (Jones, 2013) \\
\hline
\end{tabular}

methods, enhancement factors relating $\mathrm{e}_{\mathrm{s}}$ to temperature, $V P D$ application in greenhouse cultivation, and indications of high or low values can be found in the works of (Abtew and Melesse, 2013).

$$
\begin{gathered}
V P D=\exp \left(6.41+0.0727 T-310^{-4} T^{2}+1.1810^{-6} T^{3}-3.8610^{-9} T^{4}\right) \\
(1-R H / 100) .
\end{gathered}
$$

Optimal $V P D$ values are recommended in the range of 0.3 to $1.0 \mathrm{kPa}$ in different sources. For example, Barker (1990) reports that $V P D$ values between 0.5 and $0.8 \mathrm{kPa}$ are optimal for most greenhouse crops and will prevent yield reduction due to fruit shrinkage and fungal diseases. What is more, $V P D$ values between 0.2 and $1.0 \mathrm{kPa}$ are recommended for both pollination and prevention from fungal diseases (Picken 1984; Prenger and Ling 2007). Iraqi et al. (1995) suggested VPDs of $0.8 \mathrm{kPa}$ as the optimal during day and night hours, and reported that both the photosynthetic rate and yield of tomato fruits increased when compared with $V P D$ treatments of $0.5 \mathrm{kPa}$. Moreover, values between 0.2 and $1.0 \mathrm{kPa}$ were found to have little or no effect on the physiology and growth development of tomato (Grange and Hand, 1987; Picken, 1984). In another study on the effects of humidity on 26 different crops (Schwarz et al., 2014), VPD between 0.3 and $1.0 \mathrm{kPa}$ were reported to have minor effect, while values above $1.0 \mathrm{kPa}$ were found to significantly affect plant growth. It is generally recommended that $V P D$ should be kept around 0.3 $0.5 \mathrm{kPa}$ during root cuttings in order to minimize dry outs of plants, especially in dense plant conditions. This will also create a greenhouse environment that is less subjected to fungal diseases. Gautier et al. (2001) observed that optimal $V P D$ enhances tomato fruit quality (higher sugar contents and dry matter weight) under low fruit load, while, Barker (1990) reported that problems associated with calcium deficiency can be avoided by maintaining optimal $V P D$. Factsheet (2015) considered VPD values between 
0.47 and $1.27 \mathrm{kPa}$ to be most suitable, and Omafra (2005) suggested values between $0.4-0.79 \mathrm{kPa}$ to be the ideal $V P D$ for most greenhouses crops. Tomato photosynthesis and nutrient uptake were also found to be optimal in this range. A popular agronomy weblog, Just4Growers, considered values of 0.75 and $1.06 \mathrm{kPa}$ as the ideal range, and 0.45 and $1.25 \mathrm{kPa}$ as marginal borders. This source also recommends that $V P D$ below $0.45 \mathrm{kPa}$ is the set-point to activate a dehumidification system, and that values over $1.25 \mathrm{kPa}$ should trigger humidification devices such as fog systems. A commercial greenhouse company (Argus, 2009) determined $V P D$ between $0.5-1.2 \mathrm{kPa}$ to be optimal, and $0.4-1.37 \mathrm{kPa}$ to constitute marginal borders. A summary of the lower and upper optimal and marginal $T, R H$ and $V P D$, as recommended by the last four reference sources mentioned, is provided in Table 2 and is followed by a descriptive summary for different values of $V P D$ in greenhouse cultivation of tomato that is presented in Table 3 .

Table 2. Summary of lower and upper optimal and marginal $T, R H$ and $V P D$ as recommended by four references

\begin{tabular}{|c|c|c|c|c|c|c|c|c|c|c|c|c|}
\hline \multirow{2}{*}{ Reference } & \multicolumn{3}{|c|}{ Lower optimal } & \multicolumn{3}{|c|}{ Upper optimal } & \multicolumn{3}{|c|}{ Lower marginal } & \multicolumn{3}{|c|}{ Upper marginal } \\
\hline & $T\left({ }^{\circ} \mathrm{C}\right)$ & $\begin{array}{l}\text { RH } \\
(\%) \\
\end{array}$ & $\begin{array}{l}V P D \\
(\mathrm{kPa})\end{array}$ & $T\left({ }^{\circ} \mathrm{C}\right)$ & $\begin{array}{l}R H \\
(\%) \\
\end{array}$ & $\begin{array}{l}V P D \\
(\mathrm{kPa})\end{array}$ & $T\left({ }^{\circ} \mathrm{C}\right)$ & $\begin{array}{l}R H \\
(\%) \\
\end{array}$ & $\begin{array}{l}V P D \\
(\mathrm{kPa})\end{array}$ & $T\left({ }^{\circ} \mathrm{C}\right)$ & $\begin{array}{l}\text { RH } \\
(\%) \\
\end{array}$ & $\begin{array}{l}V P D \\
(\mathrm{kPa}) \\
\end{array}$ \\
\hline $\begin{array}{l}\text { (Factsheet, } \\
\text { 2015) }\end{array}$ & 15 & 60 & 0.47 & 30 & 85 & 1.27 & - & - & - & - & - & - \\
\hline $\begin{array}{l}\text { (Omafra, } \\
2005)\end{array}$ & 15 & 55 & 0.40 & 30 & 90 & 0.79 & - & - & - & - & - & - \\
\hline Just4Growers & 15 & 40 & 0.75 & 34 & 85 & 1.06 & 15 & 35 & 0.45 & 34 & 85 & 1.25 \\
\hline (Argus, 2009) & 15 & 35 & 0.50 & 35 & 90 & 1.20 & 17 & 35 & 0.40 & 34 & 90 & 1.37 \\
\hline
\end{tabular}

Ta b le 3. Optimal range of vapour pressure deficit for greenhouse cultivation as suggested by different references

\begin{tabular}{|c|c|c|}
\hline Range (kPa) & Description & Reference \\
\hline $0.2-1.0$ & $\begin{array}{l}\text { ideal for pollination and for prevention from fungal disease, this } \\
\text { range was found to have little or no negative effect on the } \\
\text { physiology and growth development of tomato }\end{array}$ & $\begin{array}{l}\text { (Picken 1984; Prenger and Ling } \\
\text { 2001; Grange and Hand } 1987\end{array}$ \\
\hline $0.3-1.0$ & $\begin{array}{l}\text { studying the effect of humidity on } 26 \text { different crops showed this } \\
\text { range has minor negative effects }\end{array}$ & (Hoffman, 1979) \\
\hline $0.4-0.79$ & $\begin{array}{l}\text { ideal for most greenhouses crops, tomato's photosynthesis and } \\
\text { nutrient uptake are optimal at this range }\end{array}$ & (Omafra, 2005) \\
\hline$<0.4$ or $>1.37$ & considered marginal values & (Argus, 2009) \\
\hline$<0.45$ or $>1.25$ & considered marginal values & Just4Growers \\
\hline $0.47-1.27$ & optimal for greenhouse cultivation & (Factsheet, 2015) \\
\hline $0.5-0.8$ & $\begin{array}{l}\text { optimal for most greenhouse crops and will prevent from yield } \\
\text { reduction due to shrinkage of fruit size and fungal diseases. }\end{array}$ & (Barker, 1990) \\
\hline $0.5-1.2$ & considered optimal & (Argus, 2009) \\
\hline $0.75-1.06$ & considered optimal & Just4Growers \\
\hline 0.8 & $\begin{array}{l}\text { optimal during day and night hours, reporting that both } \\
\text { photosynthetic rate and yield of tomato fruits increased compared } \\
\text { with treatments with } 0.5 \mathrm{kPa} V P D\end{array}$ & (Iraqi et al., 1995) \\
\hline$<0.45$ & the set-point to active dehumidification system & Just4Growers \\
\hline$>1.0$ & significantly affect plant's growth & (Hoffman, 1979) \\
\hline$>1.25 \mathrm{kPa}$ & will trigger humidification devices such as fog systems. & Just4Growers \\
\hline
\end{tabular}




\section{MICROCLIMATE EVALUATION WITH DECISION SUPPORT SYSTEM (DSS)}

\section{HYTODMOD, OptVPD, and TOMGRO models}

An interactive decision-support system (DSS) developed by Short et al., (2005), based on the HYTODMOD growth response model of El-Attal (1995), is available to describe the optimality degrees of air temperature and $R H$ at five growth stages and under three light conditions (night, sun and cloud). A graphical representation of this model for defining the optimal air temperature and $R H$ has been reproduced from the original source and is provided in Fig. 2. These functions have been tested and validated by four independent expert growers and result from experiments with tomato 'Caruso' cultivar, in an A-Shade greenhouse located at the Ohio Agriculture Research and Development Centre with a floor area of $7.3 \mathrm{~m}^{2}$. In order to develop membership functions for defining the optimality degrees of $V P D$, Shamshiri et al. (2017b) integrated the growth response model of El-Attal (1995) and developed the Opt $V P D$ model, along with a series of membership functions (Fig. 3).

Figure 3 with $V P D(\mathrm{kPa})$ as inputs, and a real number between 0 and 1 as an output that defines the optimality degree of greenhouse $V P D$ at different light conditions and growth stages of tomato. The knowledge behind the plots of Figs 2 and 3, and the optimal and failure microclimate values (Table 4), are condensed from an extensive peer reviewed scientific published research on greenhouse cultivation of tomato and physiology, with the goal of

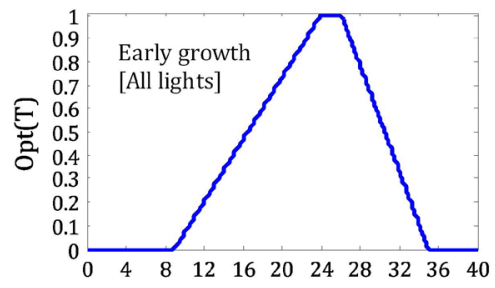

$\mathrm{T}\left({ }^{\circ} \mathrm{C}\right)$
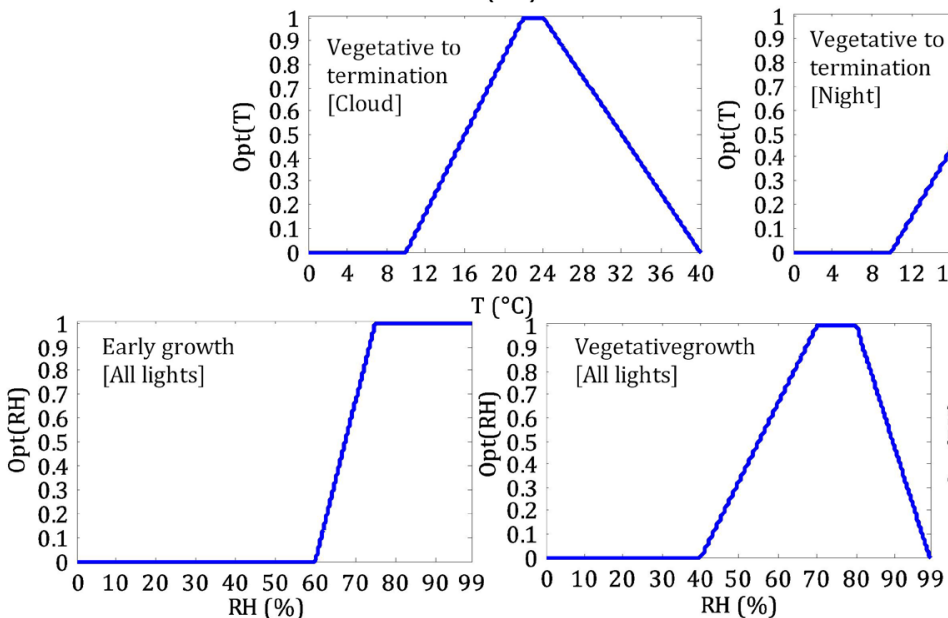

simultaneously achieving high yield and high-quality fruit. A more in-depth analysis and practical examples of this DSS are presented by Shamshiri et al. (2017a) via an adaptive management framework.

The reduced state variable TOMGRO model (Jones et al., 1999) was developed with the objective of providing a practical application with only five state variables as the node number for the main stem, the leaf area index, total plant dry weight $\left(\mathrm{W}_{\mathrm{T}}\right)$, total fruit dry weight $\left(\mathrm{W}_{\mathrm{F}}\right)$, and total mature fruit dry weight $\left(\mathrm{W}_{\mathrm{M}}\right)$. Jones et al. (1999) provided simulation results for three tomato varieties, including 'DeRuiters', 'Beefsteak' and 'Bigboy', respectively, for three experiment locations at Gainesville (Florida), Avignon (France) and Lake City (Florida). They concluded that it is possible to use the simplified TOMGRO model for different climate conditions and different tomato varieties with the same parameters derived from their experiment. This conclusion was verified for tropical climate conditions in the lowlands of Malaysia (Shamshiri et al., 2016a) using boundary data. Some of the other studies that adapted or validated TOMGRO model to specific climate conditions and cultural practices include the works of Schrevens et al. (2005), Dimokas et al. (2009) and Gallardo et al. (2009). It should be noted that the simplified TOMGRO model only takes into account the effect of air temperature and light condition, while other variables such as $\mathrm{CO}_{2}$ concentration have not been included in this version. In addition, Jones et al. (1999) did not take the work any farther than making the model calculations in an Excel spreadsheet, hence the model did not have a practical application and could not

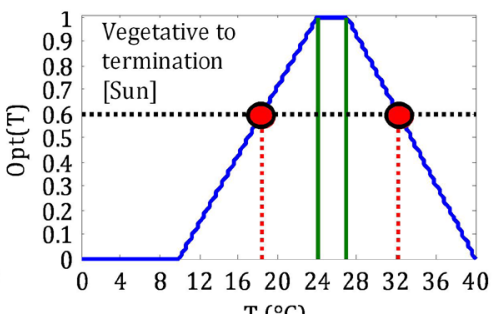
$\mathrm{T}\left({ }^{\circ} \mathrm{C}\right)$
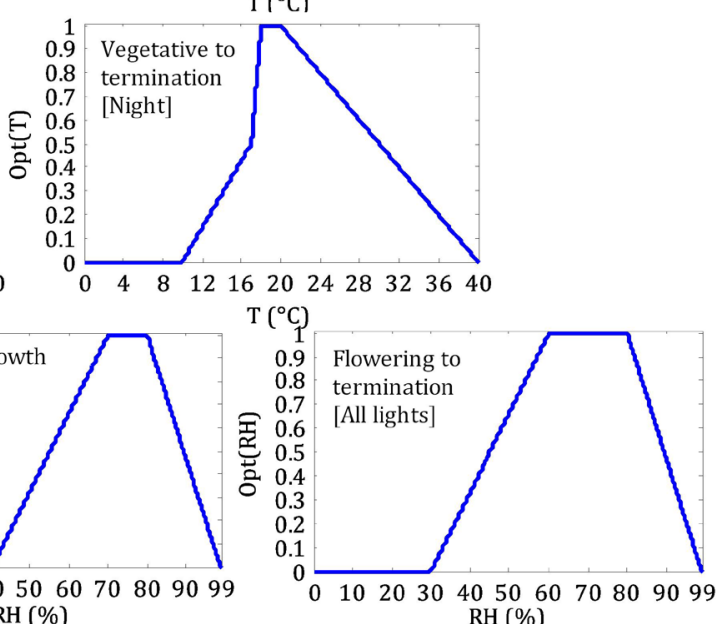

Fig. 2. Graphs of growth response function for defining optimal air temperature and relative humidity for the 'Caruso' greenhouse tomato cultivar at different growth stages and light conditions, adapted from (El-Attal, 1995). 

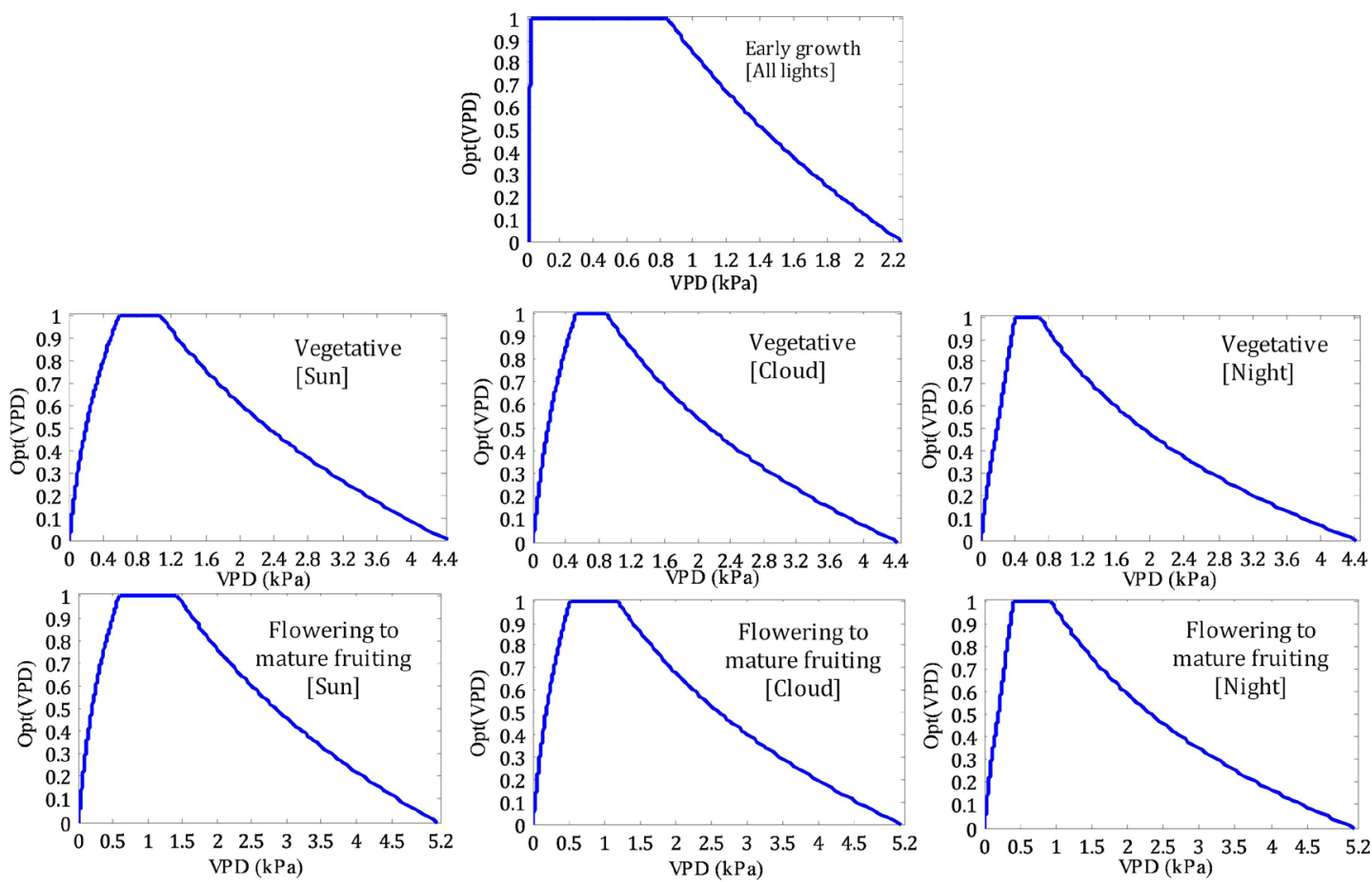

Fig. 3. Graphs of membership functions for defining optimality degrees of vapour pressure deficit at different light condition and growth stages for the 'Caruso' greenhouse tomato cultivar, adapted from (Shamshiri et al., 2017b).

Table 4. Optimal and failure values of $T, R H$ and $V P D$ for the tomato cultivar 'Carusso', according to the decision support system of Short et al. (2005)

\begin{tabular}{|c|c|c|c|c|c|c|c|c|c|c|c|c|c|}
\hline \multirow{2}{*}{$\begin{array}{l}\text { Growth } \\
\text { stage }\end{array}$} & \multirow{2}{*}{$\begin{array}{l}\text { Light } \\
\text { condition }\end{array}$} & \multicolumn{3}{|c|}{ Lower optimal } & \multicolumn{3}{|c|}{ Upper optimal } & \multicolumn{3}{|c|}{ Lower failure } & \multicolumn{3}{|c|}{ Upper failure } \\
\hline & & $T\left({ }^{\circ} \mathrm{C}\right)$ & $\begin{array}{l}R H \\
(\%)\end{array}$ & $\begin{array}{l}V P D \\
(\mathrm{kPa})\end{array}$ & $T\left({ }^{\circ} \mathrm{C}\right)$ & $\begin{array}{l}R H \\
(\%)\end{array}$ & $\begin{array}{l}V P D \\
(\mathrm{kPa})\end{array}$ & $T\left({ }^{\circ} \mathrm{C}\right)$ & $\begin{array}{l}R H \\
(\%)\end{array}$ & $\begin{array}{l}V P D \\
(\mathrm{kPa})\end{array}$ & $T\left({ }^{\circ} \mathrm{C}\right)$ & $\begin{array}{l}R H \\
(\%)\end{array}$ & $\begin{array}{l}V P D \\
(\mathrm{kPa})\end{array}$ \\
\hline \multirow[t]{2}{*}{$\begin{array}{l}\text { Early } \\
\text { growth }\end{array}$} & any & 24 & 75 & 0.2 & 26.1 & 100 & 0.845 & 9 & 60 & 0.011 & 35 & - & 2.248 \\
\hline & sun & 24 & 70 & 0.596 & 27 & 80 & 1.069 & 10 & 40 & 0.012 & 40 & 100 & 4.422 \\
\hline \multirow[t]{2}{*}{ Vegetative } & cloud & 22 & 70 & 0.528 & 24 & 80 & 0.895 & 10 & 40 & 0.012 & 40 & 100 & 4.422 \\
\hline & night & 18 & 70 & 0.413 & 20 & 80 & 0.701 & 10 & 40 & 0.012 & 40 & 100 & 4.422 \\
\hline \multirow{3}{*}{$\begin{array}{l}\text { Flowering } \\
\text { to mature } \\
\text { fruiting }\end{array}$} & sun & 24 & 60 & 0.596 & 27 & 80 & 1.425 & 10 & 30 & 0.012 & 40 & 100 & 5.160 \\
\hline & cloud & 22 & 60 & 0.528 & 24 & 80 & 1.193 & 10 & 30 & 0.012 & 40 & 100 & 5.160 \\
\hline & night & 18 & 60 & 0.413 & 20 & 80 & 0.935 & 10 & 30 & 0.012 & 40 & 100 & 5.160 \\
\hline
\end{tabular}

be used by greenhouse growers. To overcome this limitation, Shamshiri et al. (2017a) extended and implemented the TOMGRO model in SIMULINK and interfaced it with the HYTODMOD and Opt $V P D$ for microclimate evaluation and yield estimation.

\section{Microclimate evaluation}

The interfaced HYTODMOD, Opt $V P D$, and TOMGRO model can be used as evaluation tools for exploring optimality degrees of microclimate, as well as for generating yield estimation depending on the growth stage of the plant and different light condition. It also allows growers to manually change the values of the growing parameters and the growth stages and also to receive feedback by means of a number between 0 and 1 representing how close that parameter is to high yield and high quality. An application of this DSS has been presented for dynamic assessment (Shamshiri et $a l ., 2017 \mathrm{c}$ ), for measuring optimality degrees (Shamshiri, 2017), and for establishing a comparative evaluation of microclimate parameters (Shamshiri et al., 2016b) in greenhouses with different covering materials. Microclimate 
evaluation with $V P D$ influences the energy costs involved in greenhouse cultivation and must be taken into account in humidity and temperature control algorithms. It should be noted that $V P D$ cannot be directly controlled since its value is not unique. Therefore, it should not be used directly as feedback of a closed-loop climate control system. For example, $V P D=0.85 \mathrm{kPa}$ can result from different combinations of air temperature and $R H$ (i.e., $T=15^{\circ} \mathrm{C}$ and $R H=$ $50 \%$, or $T=34^{\circ} \mathrm{C}$ and $R H=84 \%$ ). The relationship between air temperature, $R H$ and $V P D$, when one parameter is kept constant, can be described using Table 5 and Fig 4. It can be seen that for a constant $R H$, the values of $V P D$ increase at higher temperatures, resulting in an increase in the plant transpiration rate. The mathematical expression of $V P D$ indicates that the maximum $V P D$ value in a set belongs to a maximum temperature and minimum $R H$ combination. Likewise, when air temperature is at the lowest value in the greenhouse and $R H$ is at the highest level, $V P D$ is minimized. The figures displayed in Fig. 4 reveal that in order to maintain healthy $V P D$ values at $R H=70-75 \%$, air temperature should be kept between 24 and $29^{\circ} \mathrm{C}$. Table 5 also explains that at a constant $R H$, when air temperature increases from 20 to $30^{\circ} \mathrm{C}, V P D$ changes from 0.58 to $1.06 \mathrm{kPa}$. Moreover, at constant $V P D$, increasing air temperature from 14 to $34^{\circ} \mathrm{C}$ results in variation in $R H$ from 47 to $84 \%$. Of note, $V P D$ can be effectively controlled by humidification devices such as fogging systems. Furthermore, as a general rule, increasing air temperature in the greenhouse by minimizing ventilation will increase $V P D$, while activating the evaporative cooling system, misting or fogging will cause higher RH, thus decreasing VPD. Psychrometric and ventilation constraints for $V P D$ have been discussed in the work of Zolnier et al. (2000).

The results of studying fogging system VPD controllers on growth development and productivity of tomato in winter season (Lu et al., 2015) showed that, on average,

Table 5. Variation in vapour pressure deficit due to different combination of temperature and relative humidity

\begin{tabular}{|c|c|c|c|c|c|c|c|c|}
\hline \multicolumn{3}{|c|}{ Constant temperature } & \multicolumn{3}{|c|}{ Constant relative humidity } & \multicolumn{3}{|c|}{ Constant $V P D$} \\
\hline$T\left({ }^{\circ} \mathrm{C}\right)$ & $R H(\%)$ & $\begin{array}{l}V P D \\
(\mathrm{kPa})\end{array}$ & $T\left({ }^{\circ} \mathrm{C}\right)$ & $R H(\%)$ & $\begin{array}{l}V P D \\
(\mathrm{kPa})\end{array}$ & $T\left({ }^{\circ} \mathrm{C}\right)$ & $R H(\%)$ & $\begin{array}{l}V P D \\
(\mathrm{kPa}) \\
\end{array}$ \\
\hline \multirow{11}{*}{25} & 45 & 1.741 & 20 & & 0.584 & 14 & 47 & 0.847 \\
\hline & 50 & 1.583 & 21 & & 0.621 & 15 & 50 & 0.852 \\
\hline & 55 & 1.425 & 22 & & 0.661 & 16 & 53 & 0.854 \\
\hline & 60 & 1.266 & 23 & & 0.702 & 17 & 56 & 0.852 \\
\hline & 65 & 1.108 & 24 & & 0.745 & 18 & 59 & 0.846 \\
\hline & 70 & 0.950 & 25 & 75 & 0.791 & 22 & 68 & 0.845 \\
\hline & 75 & 0.791 & 26 & & 0.840 & 25 & 73 & 0.855 \\
\hline & 80 & 0.633 & 27 & & 0.891 & 30 & 80 & 0.848 \\
\hline & 85 & 0.475 & 28 & & 0.944 & 31 & 81 & 0.853 \\
\hline & 90 & 0.317 & 29 & & 1.001 & 33 & 83 & 0.855 \\
\hline & 95 & 0.158 & 30 & & 1.060 & 34 & 84 & 0.851 \\
\hline
\end{tabular}
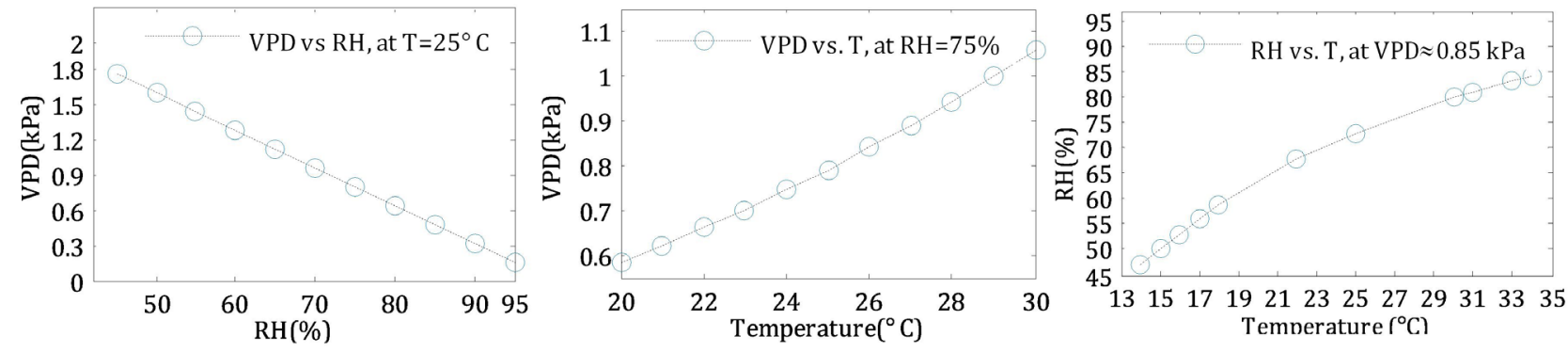

Fig. 4. Demonstration of $V P D$ in relation to variable and constant $T$ and $R H$. 
$V P D$ values decreased from 1.4 to $0.8 \mathrm{kPa}$, leading to an increase in the net photosynthetic rate, and to $17.3 \%$ average biomass and $12.35 \%$ yield increases. The same study also showed that during the winter season, the greenhouse $V P D$ of approached $1.0 \mathrm{kPa}$ in the absence of fogging in the middle of the days. Studies also show that using microfog systems for $V P D$ control during the summer season can effectively enhance the growth and productivity of tomato, and can result in a substantial biomass and yield increase by improving photosynthesis (Zhang et al., 2015). What is more, increasing air temperature by $2{ }^{\circ} \mathrm{C}$ in the winter season, in the hours of high humidity, is recommended to maintain optimal VPD (Sato et al., 2000). However, pollen development may be reduced in the summer season if air temperature is too high (Sato et al., 2000; Peet et al., 2003). Portree (1996) reported a similar effect with too low air temperature at night hours (below $16^{\circ} \mathrm{C}$ ), recommending a possible compensation with day temperatures. The increase in air temperature caused by a greenhouse environment (compared with an open environment) depends on the characteristics of the covering material, wind velocity, intensity of solar radiation and the transpiration of tomato plants. While day temperatures are significantly higher in greenhouses than in an open environment, night temperatures are only increased by 2 to $4^{\circ} \mathrm{C}$, or in some cases, they are even lower than under open-field conditions (thermal inversion). Reports of an experimental study (Shamshiri et al., 2016b) with two empty research greenhouses, one covered with polyethylene film without a climate control system, and the other with polycarbonate panels and with an evaporative cooling system, showed that while the $\mathrm{T}$ and $R H$ of the outside air were, respectively, between $25-35^{\circ} \mathrm{C}$ and $55-95 \%$, the inside microclimate reached $T=68-70^{\circ} \mathrm{C}$ and $R H=26-79 \%$ for the polyethylene greenhouse, and $T=25-40^{\circ} \mathrm{C}$ and $R H=47-93 \%$ for the polycarbonate greenhouse, with averaged maximum $V P D$ of 13.6 and $3.9 \mathrm{kPa}$, respectively. Plots of $24 \mathrm{~h}$ average data for this experiment are shown in Fig. 5 and reveal that both temperatures and $V P D$ are slightly affected by the greenhouse environment during night hours.

\section{PRODUCTION CONSTRAINTS WITH ADVERSE MICROCLIMATE}

\section{Effects of suboptimal temperature}

Shoot dry matter content and partitioning of tomato are affected by temperatures (Adams et al., 2001). Indeed, tomato crops that suffer from heat stress have yields that are expected to decrease by $12.6 \%$ for every $1.2^{\circ} \mathrm{C}$ increase in temperature above $25^{\circ} \mathrm{C}$, assuming that yield has a nonlinear response, and the optimum and failure temperature are 23.5 and $30^{\circ} \mathrm{C}$, respectively (Sato et al., 2000). Air temperature higher or lower than the optimal values affects different phases of growth and development of tomato, as well as the overall fruit appearance and quality (Van Ploeg and Heuvelink, 2005). Baudoin et al. (2013) reported that when test plants were subjected to a persistent temperature below $10-12^{\circ} \mathrm{C}$ for several days, their productivity was affected. Moreover, it was observed that in low $R H$ condition, air temperature above $30^{\circ} \mathrm{C}$, and in high $R H$ condition, temperature above $30-35^{\circ} \mathrm{C}$ reduces tomato productivity (Baudoin et al., 2013). High temperatures cause fruit abortion and flaccid leaves because of improper transpiration, and can even destroy the plant. Tomato plants are notably sensitive to above-optimal air temperatures during the reproductive stage and may face a reduction in the percentage of fruit set, which triggers a significant yield decrease in commercial cultivation. In a study on the possible relationship between the reproductive stage of tomato and the average daily air temperature (Harel et al., 2014), it was found that fruit number, the percentage of fruit set and fruit weight per plant decreased along with air temperature increase from 25 to $29^{\circ} \mathrm{C}$. When temperatures are high, plants tend to transpire more. In such situations, yield reduction is mainly caused by the impaired pollen, another development and reduced pollen viability (Sato et al., 2006). Values higher than $35^{\circ} \mathrm{C}$ will also reduce fruit set and delay the development of normal fruit colours (Jones, 2013). During the late maturation growth stage, tomato fruits also become more sensitive to high temperatures, and the rates of fruit growth volume are affected. Moreover, a high air temperature combined with too low $R H$ values induces flower abortion.

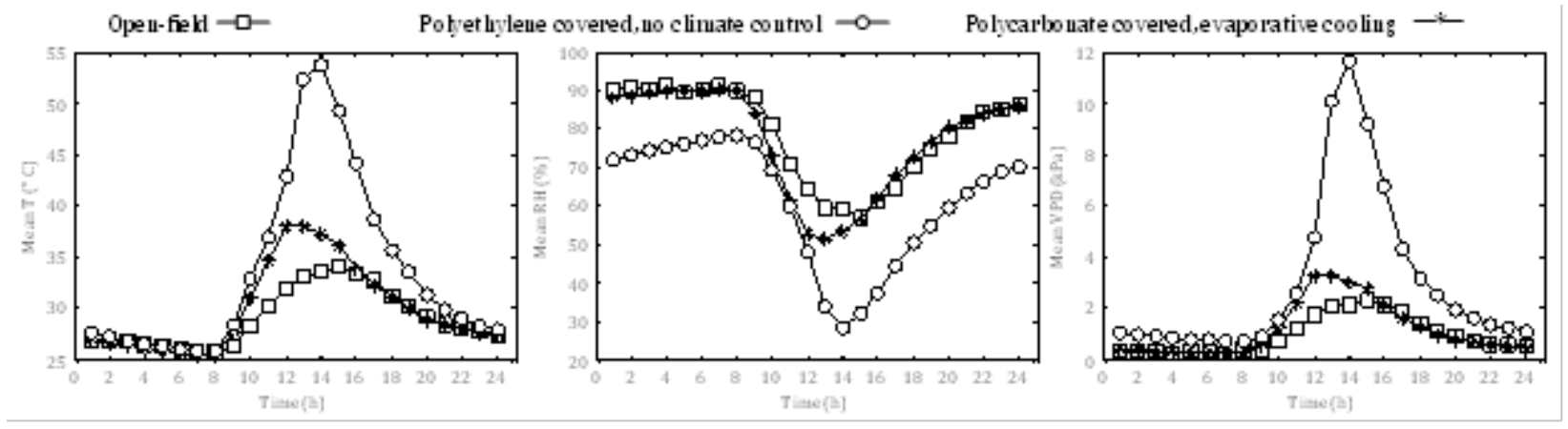

Fig. 5. Effects of greenhouse cladding and cooling systems on day and night $T, R H$ and $V P D$ under tropical climate conditions (Shamshiri et al., 2016b). 
Adams et al. (2001) reported that air temperature regimes lower than $14^{\circ} \mathrm{C}$ and higher than $26^{\circ} \mathrm{C}$ brought about small parthenocarpic fruits combined with low flower numbers and poor fruit set, resulting in decreased yields. Air temperature below $10^{\circ} \mathrm{C}$ was also shown to delay germination of seeds, inhibit vegetative development, shrink fruit set and impair fruit ripening (Jones, 2013). De Koning (1994) also reported that the mature fruiting growth stage was extended in treatments with low temperatures. In addition, in temperatures below $12.7^{\circ} \mathrm{C}$, especially during night hours, tomato blossom drop will occur. Indeed, no significant growth and development in tomato plants were observed by Criddle et al. (1997) below an average temperature of $12^{\circ} \mathrm{C}$. Still, Khayat et al. (1985) concluded that the effects of sub-optimal air temperature on tomato yields also depended on the cultivar. For example, while an average night air temperature of $12^{\circ} \mathrm{C}$ resulted in $76 \%$ of the yield obtained at $18^{\circ} \mathrm{C}$ for the 'Moneymaker' cultivar, it did not affect the growth of the 'Cherry' cultivar. Van Ploeg and Heuvelink (2005) also reported that chilling temperatures had negative effects on respiration and photosynthesis, and caused hormone imbalance in the plants. What is more, an average temperature of $14^{\circ} \mathrm{C}$ was found to result in smaller and harder tomato fruits with no marketable value (Adams et al., 2001). In addition, tomato plants exposed to cool air temperatures below $18.3^{\circ} \mathrm{C}$ for long hours would flower profusely, with their flower clusters growing at the terminals (Jones, 2013). Vanthoor et al. (2011) noted that an average low temperature between 13 and $15^{\circ} \mathrm{C}$ may have positive effects on yield, but only at lower light levels. For example, with a low light condition of $7.6 \mathrm{MJ} \mathrm{m}^{-2}$ day $^{-1}$, an average night temperature of $13.2^{\circ} \mathrm{C}$ increased tomato yield to $108 \%$ in relation to that obtained in $15.2^{\circ} \mathrm{C}$, while no significant effect, in terms of yield increase, was observed under higher light conditions of $9.4 \mathrm{MJ} \mathrm{m}^{-2} \mathrm{day}^{-1}$. However, the reviewed literature suggests that as air temperature increases from 18 to $29^{\circ} \mathrm{C}$, the fruit growth period decreases approximately from 70 days to 40 days, while both yield and quality are improved, having their optimum values between 24 and $27^{\circ} \mathrm{C}$.

\section{Effects of suboptimal humidity}

Various parameters, including the photosynthetic rate, morphology, yield and disease occurrence, are affected by greenhouse $R H$. Recommendations indicate that tomato grows better in relatively dry air. Liu et al. (2006) observed that $R H$ between 55 and $90 \%$, (corresponding to $V P D$ of 0.2 and $1 . \mathrm{kPa}$ ) does not have any negative effects on photosynthesis. In contrast, too much $R H$ can stop transpiring and may result in turgor losses in plants. Indeed, Huang et al. (2011) found that, in comparison to $30-40 \%$ $R H$, pollen and fertilization of tomato was improved in $R H$ between $60-70 \%$. However, $R H$ higher than $90 \%$ may increase pollen susceptibility to heat stress (Nepi et al.,
2010). In a highly humid greenhouse environment, diseases and fungal pathogens spread rapidly and infect plants. In tropical climate, pests and diseases spread faster due to high temperatures and humidity. Some of the diseases and physiological abnormalities associated with high humidity in greenhouse production include black spot, powdery mildew, leaf-edge burn in poinsettia and blossom-end rot of tomatoes. Other than that, plants evapotranspiration may be limited. Blossom end rot is partially related to low transpiration rates, and may be more likely to occur when $R H$ is high. Moreover, calcium deficiency in tomato leaves is reported to be associated with high humidity and reduction of leaf area (Holder and Cockshull, 1990). Choi et al. (1997) reported that tomato fruit quality was reduced by high $24 \mathrm{~h}$ average humidity, while leaf area and shoot dry weight increased with high night humidity. Concentrations of nitrogen, phosphors, potassium, calcium and magnesium have been reported to decrease under high night humidity, with the calcium content in younger leaves being the most severely affected (Triguii et al., 1999). Other problems associated with high and low temperatures and $R H$ values were extensively discussed by Cohen et al. (2005). Detailed effects of humidity on tomato growth and production can be found in the works of Barker (1990) and Triguii et al. (1999). The following effects of high $R H$ have been reported: disease and fungal pathogens spreading, disease occurrence (including black spot, powdery mildew, leaf-edge burn in poinsettia and blossom-end rot), low transpiration rates, blossom end rot, nitrogen, phosphors, potassium, calcium and magnesium deficiency, reduced fruit quality, increased leaf area and shoot dry weight.

\section{Effects of suboptimal vapour pressure deficit}

Various effects of high VPD on tomato fruit quality, growth and transpiration are discussed in the work of Leonardi et al. (2000). VPD directly affects water uptake by tomato plants and the overall tomato fruit yield. What is more, extremely high or low VPD values can result in leaf physiology disorders and development failure (Gautier et al., 2001). Values of $V P D$ larger than $1.0 \mathrm{kPa}$ show the potential of air for holding more water vapour, enabling plants to transpire more. A low $V P D$ indicates that $\mathrm{e}_{\mathrm{s}}$ is very close to $\mathrm{e}_{\mathrm{d}}$. When $V P D$ is zero $\left(\mathrm{e}_{\mathrm{s}}=\mathrm{e}_{\mathrm{d}}\right)$, plants can hardly transpire. At a constant temperature, low and high $V P D$, respectively, indicate high and low levels of $R H$ under greenhouse conditions. In a hot and humid tropical climate, low VPD rapidly leads to condensation dripping from the greenhouse cover (Shamshiri et al., 2014), causing fungal spore contamination. Mineral deficiencies also appear due to low sap movement in the plant. Evaporative pad-andfan systems can cause low VPD in tropical greenhouses by increasing $R H$ without significantly reducing air temperature, and accelerate the spread of fungal diseases (Xu et al., 2015). In arid climate conditions, improper environment 
control of greenhouse can result in high VPD between 3-5 $\mathrm{kPa}$, which leads to poor growth because tomato plants roots cannot compensate for the transpired water, thus, blossom-end rot and stomatal closure are likely to occur. Shamshiri et al. (2014) showed that maintaining an optimum $V P D$ caused the hourly water uptake rate to increase by 35 to $50 \%$. Furthermore, they noted that increases in water uptake, up to $800 \mathrm{ml} \mathrm{plant}^{-1} \mathrm{~d}^{-1}$, led to a higher crop yield. It should be underlined that tomato plants stop transpiring water into the air as a result of low $V P D$, causing an increase in pressure within the plants. In a study of the $V P D$ effect in the range of $0.35-1.0 \mathrm{kPa}$ in daytime, and 0.2-0.7 $\mathrm{kPa}$ in night time, Barker (1990) showed that low VPD reduced the leaf area index due to calcium deficiency, as well as average fruit weight and final yield, while increasing stomatal conductance. Because calcium moves through the xylem, it is affected by transpiration. Calcium deficiency leads to blossom end rot, especially in the presence of other stress factors (Barker, 1990; Holder and Cockshull, 1990). In addition, high solar radiation generates excessive transpiration and more accumulation of calcium in tomato leaves than in the fruits. Plant transpiration may be blocked at low $V P D$ which influences the energy balance of the canopy. Fungal pathogens and mineral deficiency symptoms appear below a $V P D$ value of $0.43 \mathrm{kPa}$, and disease infection can be most damaging below a $V P D$ value of $0.2 \mathrm{kPa}$. Janse and Welles (1984) observed that fruits that are grown at low $V P D$ generally become softer more quickly, and have lower quality and shorter shelf life. Still, early tomato yield was increased by low VPD during daytime, however, both day and night low VPD values reduced final yield and average fruit quality (Holder and Cockshull, 1990). In contrast, lower $V P D$ values cause larger and thicker leaves and stems, and they weaken the root system as a result of efforts to compensate restricted transpiration. Reports of several studies indicate that $V P D$ values below $0.2 \mathrm{kPa}$ or above $2.2 \mathrm{kPa}$, respectively, representing highly humid and too dry greenhouse environments, increase the risk for fungal pathogen spreading and physiological disorders in tomato plants. In summary, low $V P D$ values (below $0.3 \mathrm{kPa}$ ) in tomato plants cause mineral deficiencies, guttation, fungal diseases and soft growth, while high VPD (larger than $1.5 \mathrm{kPa})$ results in wilting, lear roll, stunted plants and crispy leaves.

\section{RECAPITULATIONS}

The aim of this paper was to review and summarize the optimal values of air and root-zone temperature, relative humidity and vapour pressure deficit for successful greenhouse cultivation of tomato. These values were gathered from extensive research publications on the physiology of greenhouse tomato, with the goal of simultaneously achieving high yield and high-quality fruit. The application of a decision-support system was highlighted in determining how close greenhouse microclimate parameters are to the optimum condition, and how changes in each variable may affect the final yield. The presented approach can be used in a cost-benefit analysis for providing the best management decisions related, inter alia, to site selection, optimum growing season, scheduling efficiencies, energy management with different climate control systems, and risk assessments associated with each task. Effects of each parameter on the fruit quality and yield, and the associated problems with suboptimal values, were reviewed and summarized. It can be concluded that the effects of high or low temperatures may vary with different levels of humidity, light condition, intensity of solar radiation and $\mathrm{CO}_{2}$ concentration. However, a decreasing trend in total fruit weight can be observed, assuming the average levels of other parameters. Both results of this review and the summarized values can be used in task planning algorithms for hierarchical decomposition of microclimate management and tomato growth models. The review can also contribute to generating the best economic models of tomato for energy conservation and energy efficient greenhouse crop productions. The cost of an increased automation level, relative to an increase in profitability, is a key consideration and should form part of future studies to justify the implementation of a greater level of automation.

\section{ACKNOWLEDGEMENT}

The scientific comments and suggestions from Professor Ray Bucklin at the University of Florida, Professor Cornelia Weltzien at the Leibniz Institute for Agricultural Engineering (ATB), Professor Wang Yingkuan of Chinese Academy of Agricultural Engineering, and Dr. Jan Bontsema are duly acknowledged.

Conflict of interest: The authors do not have conflict of interest.

\section{REFERENCES}

Abtew W. and Melesse A., 2013. Evaporation and evapotranspiration: Measurements and estimations. Springer Sci., 53, 62, http://doi.org/10.1007/978-94-007-4737-1

Adams S.R., Cockshull K.E., and Cave C.R.J., 2001. Effect of temperature on the growth and development of tomato fruits. Annals of Botany, 88(5), 869-877, http://dx.doi. org/10.1006/anbo.2001.1524

Ajwang P.O. and Tantau H.J., 2005. Prediction of the effect of insect-proof screens on climate in a naturally ventilated greenhouse in humid tropical climates. Acta Horticulturae, Int. Soc. Horticultural Sci. (ISHS), Leuven, Belgium, pp. 449-456, https://doi.org/10.17660/ActaHortic.2005.691.54

ASABE Standard (ANSI/ASAE EP406.4) 2015. Heating, ventilating and cooling greenhouses, American Society of Agricultural and Biological Engineers. St. Joseph, MI, USA. http://citeseerx.ist.psu.edu/viewdoc/download?doi=1 $0.1 .1 .214 .2050 \&$ rep $=$ rep $1 \&$ type $=$ pdf 
Argus, 2009. Understanding and Using VPD Argus Application Note, Argus Control Systems Ltd. White Rock. http://www. arguscontrols.com/resources/VPD_Application_Note.pdf

Barker J.C., 1990. Effects of day and night humidity on yield and fruit quality of glasshouse tomatoes (Lycopersicon esculentum Mill.). J. Horticultural Sci., 65(3), 323-331, https://doi. org/10.1080/00221589.1990.11516061

Baudoin W., Nono-Womdim R., Lutaladio N., Hodder A., Castilla N., Leonardi C., De Pascale S., Qaryouti M., and Duffy R., 2013. Good agricultural practices for greenhouse vegetable crops: principles for mediterranean climate areas, Fao.

Chen R., Kang S., Hao X., Li F., Du T., Qiu R., and Chen J., 2015. Variations in tomato yield and quality in relation to soil properties and evapotranspiration under greenhouse condition. Scientia Hort., 197(3), 318-328. http://dx.doi. org/10.1016/j.scienta.2015.09.047

Cherie E., 2010. The Complete Guide to Growing Tomatoes: A Complete Step-by-Step Guide Including Heirloom Tomatoes (Back-to-Basics Gardening).

Choi J.H., Chung G.C., and Suh S.R., 1997. Effect of night humidity on the vegetative growth and the mineral composition of tomato and strawberry plants. Scientia Hort., 70(4), 293-299, http://www.sciencedirect.com/science/article/pii/S0304423897000551

Cohen S., Raveh E., Li Y., Grava A., Goldschmidh E.E., 2005. Physiological responses of leaves, tree growth and fruit yield of grapefruit trees under reflective shade screens. Scientia Hort., 107(1), 25-35. http://www.sciencedirect. com/science/article/pii/S0304423805002128

Criddle R.S., Smith B.N., and Hansen L.D., 1997. A respiration based description of plant growth rate responses to temperature. Planta, 201(4), 441-445, https://doi.org/10.1007/ s004250050087.

Dimokas G., Tchamitchian M., and Kittas C., 2009. Calibration and validation of a biological model to simulate the development and production of tomatoes in Mediterranean greenhouses during winter period. Biosystems Eng., 103(2), 217-227, http://dx.doi.org/10.1016/j.biosystemseng.2009. 01.004 .

Duchowski P. and Brazaitytë A., 2001. Tomato photosynthesis monitoring in investigations on tolerance to low temperatures. In: Acta Horticulturae. Int. Soc. Horticultural Sci. (ISHS), Leuven, Belgium, 335-339, https://doi. org/10.17660/ActaHortic.2001.562.39.

El-Attal A., 1995. Decision model for hydroponic tomato production (HYTOMOD) using utility theory, Ph.D. Thesis, Ohio State University, Columbus, Ohio.

Factsheet, 2015. Understanding Humidity Control in Greenhouses. Publication of the Canadian Ministry of Agriculture. British Columbia. Available at: https:/www2.gov.bc.ca/assets/ gov/farming-natural-resources-and-industry/agricultureand-seafood/animal-and-crops/crop-production/ understanding humidity_control.pdf.

Gallardo M., Thompson R.B., Rodriguez J.S., Rodriguez F., Fernández M.D., Sánchez J.A., and Magán J.J., 2009. Simulation of transpiration, drainage, $\mathrm{N}$ uptake, nitrate leaching, and $\mathrm{N}$ uptake concentration in tomato grown in open substrate. Agricultural Water Manag., 96(12), 1773-1784.

Garcia M.L., Medrano E., Sanchez-Guerrero M.C., and Lorenzo P., 2011. Climatic effects of two cooling systems in greenhouses in the Mediterranean area: External mobile shading and fog system. Biosystems Eng., 108(2), 133-143.

Gautier H., Guichard S., and Tchamitchian M., 2001. Modulation of competition between fruits and leaves by flower pruning and water fogging, and consequences on tomato leaf and fruit growth. Annals of Botany, 88(4), 645652, http://dx.doi.org/10.1006/anbo.2001.1518.

Grange R.I. and Hand D.W., 1987. A review of the effects of atmospheric humidity on the growth of horticultural crops. J. Horticultural Sci., 62(2), 125-134, https://doi.org/10.108 0/14620316.1987.11515760.

Harel D., Fadida H., Slepoy A., Gantz S., and Shilo K., 2014. The effect of mean daily temperature and relative humidity on pollen, fruit set and yield of tomato grown in commercial protected cultivation. Agronomy., 4(1), 167-177.

Hochmuth G.J. and Hochmuth R.C., 2012. Production of greenhouse tomatoes - Florida greenhouse vegetable production handbook, Selection of Cultivars. Production, 3, 1-18.

Hoffman G.J., 1979. Humidity. Controlled Environment Guidelines Plant Res., 141-172.

Holder R. and Cockshull K.E., 1990. Effects of humidity on the growth and yield of glasshouse tomatoes. J. Hort. Sci., 65(1), 31-39, https://doi.org/10.1080/00221589.1990.1151 6025 .

Huang Y., Li Y., and Wen X., 2011. The effect of relative humidity on pollen vigor and fruit setting rate of greenhouse tomato under high temperature condition. Acta Agric. Boreali-Occident. Sin, 11, 1-20.

Iraqi Dr., Gagnon S., Dubé S., and Gosselin A., 1995. Vapor pressure deficit (VPD) effects on the physiology and yield of greenhouse tomato. HortScience, 30(4), 846-846.

Jain N., 2012. Tomato cultivation in open fields and greenhouses. A guideline booklet. NaanDanJain Irrigation Ltd. Israel. http://www.naandanjain.com/uploads/catalogerfiles/tomato-2/Tomato_eng_booklet_190812final\%20.pdf

Janse J. and Welles G.W.H., 1984. Effects of energy saving measures on keeping quality of tomato and cucumber fruits. In Symposium on Quality of Vegetables. Jun 18. 163, 261270, https://doi.org/10.17660/ActaHortic.1984.163.29

Jensen M.E., Burman R.D., and Allen R.G., 1990. Evapotranspiration and Irrigation Water Requirements. Book Manual of Practice No.: 70. American Society of Civil Engineers, New York, NY, https://doi.org/10.1061/ 9780784414057

Jones J.B., 2013. Instructions for Growing Tomatoes in the Garden and Green-House. GroSystems, Anderson, SC, USA.

Jones J.W., Dayan E., Allen L.H., Van Keulen H., and Challa H., 1991. A dynamic tomato growth and yield model (TOMGRO). Trans. ASAE, 34(2), 663-0672.

Jones J.W., Kenig A., and Vallejos C.E., 1999. Reduced statevariable tomato growth model. Trans. ASAE, 42, 255-265.

Kawasaki Y., Satoshi M., Yoshinori K., and Koki K., 2014. Effect of root-zone heating on root growth and activity, nutrient uptake, and fruit yield of tomato at low air temperatures. J. Japanese Society Horticultural Sci., 83(4), 295-301, doi:10.2503/jjshs1.MI-001

Khayat E., Ravad D., and Zieslin N., 1985. The effects of various night-temperature regimes on the vegetative growth 
and fruit production of tomato plants. Sci. Hort., 27(1), 9-13, http://www.sciencedirect.com/science/article/pii/030 4423885900494.

Kittas C., Karamanis M., and Katsoulas N., 2005. Air temperature regime in a forced ventilated greenhouse with rose crop. Energy Buildings, 37(8), 807-812, http:/www.sciencedirect.com/science/article/pii/S0378778804003433

de Koning A.N.M., 1994. Development and dry matter distribution in glasshouse tomato : a quantitative approach. [S.1.]: De Koning. Available at: http://edepot.wur.nl/205947.

Leonardi C., Baille A., and Guichard S., 2000. Predicting transpiration of shaded and non-shaded tomato fruits under greenhouse environments. Scientia Hort., 84(3), 297-307, http://www.sciencedirect.com/science/article/pii/ S0304423899001302.

Li Y., Wen X., Li L., and Song M., 2014. The effect of root-zone temperature on temperature difference between leaf and air in tomato plants. Acta Hortic., 1107, 251-256, DOI: 10.17660/ActaHortic.2015.1107.34

Liu F., Cohen Y., Fuchs M., Plaut Z., and Grava A., 2006. The effect of vapor pressure deficit on leaf area and water transport in flower stems of soil-less culture rose. Agricultural Water Manag., 81(1-2), 216-224.

Lu N., Nukaya T., Kamimura T., Zhang D., Kurimoto I., Takagaki M., Maruo T., Kozai T. and Yamori W., 2015. Control of vapor pressure deficit (VPD) in greenhouse enhanced tomato growth and productivity during the winter season. Scientia Horticulturae, 197, 17-23, https://www.sciencedirect.com/science/article/pii/S0304423815302752

Mahajan G. and Singh K.G., 2006. Response of Greenhouse tomato to irrigation and fertigation. Agric. Water Manag., 84(1), 202-206, http://www.sciencedirect.com/science/article/pii/S0378377406000953

Morison J.I. and Morecroft M.D., 2008. Plant growth and climate change. John Wiley and Sons. http://doi.wiley. com/10.1002/9780470988695

Nepi M., Cresti L., Guarnieri M., and Pacini E., 2010. Effect of relative humidity on water content, viability and carbohydrate profile of Petunia hybrida and Cucurbita pepo pollen. Plant Systematics Evolution, 284(1-2), 57-64.

Ntatsi G., Savvas D., Huntenburg K., Druege U., Hincha D.K., Zuther E., and Schwarz D., 2014. A study on ABA involvement in the response of tomato to suboptimal root temperature using reciprocal grafts with notabilis, a null mutant in the ABA-biosynthesis gene LeNCED1. Environmental and experimental botany, 97, 11-21. https://www. sciencedirect.com/science/article/pii/S0098847213001408

Olson S.M., Stall W.M., Vallad G.E., Webb S.E., Smith S.A., Simonne E.H., McAvoy E.J., Santos B.M., and OzoresHampton M., 2012. Tomato production in Florida. EDIS. University of Florida Extension Circ HS739: University of Florida/IFAS

Omafra S., 2005. Growing Greenhouse Vegetables. Guelph, Ontario, Canada: Ontario Ministry of Agriculture, Food, and Rural Affairs.

Peet M., Sato S., Clément C., and Pressman E., 2002. August. Heat stress increases sensitivity of pollen, fruit and seed production in tomatoes (Lycopersicon esculentum Mill.) to non-optimal vapor pressure deficits. Acta Horticulturae. Int. Soc. Hort. Sci. (ISHS), Leuven, Belgium, 209-215, https:// doi.org/10.17660/ActaHortic.2003.618.23
Picken A.J.F., 1984. A review of pollination and fruit set in the tomato (Lycopersicon esculentum Mill.). J. Hort. Sci., 59(1), 1-13, https://doi.org/10.1080/00221589.1984.11515163

Popovski K., 1997. Greenhouse climate factors. Geo-heat center Quarterly Bulletin, 18(1), 14-20.

Portree J., 1996. Greenhouse vegetable production guide for commercial growers. Province of British Columbia Ministry of Agriculture, Fisheries and Food.

Prenger J.J. and Ling P.P., 2001. Greenhouse Condensation Control Understanding and Using Vapor Pressure Deficit $(V P D)$.

Prenger J.J. and Ling P.P., 2007. Ohio State University Fact Sheet Food, Agricultural and Biological Engineering Greenhouse Condensation Control - An Introduction. AEX800-00, 1-3.

Sato S., Kamiyama M., Iwata T., Makita N., Furukawa H., and Ikeda H., 2006. Moderate increase of mean daily temperature adversely affects fruit set of Lycopersicon esculentum by disrupting specific physiological processes in male reproductive development. Annals Botany, 97(5), 731-738.

Sato S., Peet M.M., and Thomas J.F., 2000. Physiological factors limit fruit set of tomato (Lycopersicon esculentum Mill.) under chronic, mild heat stress. Plant, Cell Environ., 23(7), 719-726,: http://dx.doi.org/10.1046/j.1365-3040. 2000.00589.x

Schwarz D., Thompson A.J., and Kläring H.-P., 2014. Guidelines to use tomato in experiments with a controlled environment. Frontiers Plant Sci., 5 (November), 625. http://www.ncbi.nlm.nih.gov/pubmed/25477888\%5 Cnhttp://www.pubmedcentral.nih.gov/articlerender. fcgi?artid=PMC4235429

Shamshiri R., 2017. Measuring optimality degrees of microclimate parameters in protected cultivation of tomato under tropical climate condition. Measurement, http://www.sciencedirect.com/science/article/pii/S0263224117301276

Shamshiri R., Ahmad D., Zakaria A., Ismail W.I.W., Man H.C. and Yamin M., 2016a. Evaluation of the Reduced State-Variable TOMGRO Model using Boundary Data. 2016 ASABE Annual Int. Meeting, July, 17-20, 2016. Orlando, Florida, USA. http://elibrary.asabe.org/ abstract. asp?aid $=46785 \& \mathrm{t}=5$

Shamshiri R., Ahmad D., Ismail W.I.W., Man H.C., Zakaria A., Yamin M., and van Beveren P., 2016b. Comparative evaluation of naturally ventilated screenhouse and evaporative cooled greenhouse based on optimal vapor pressure deficit. ASABE Annual Int. Meeting, July, 17-20, Orlando, Florida, USA, doi: 10.13031/aim.20162454215, http://elibrary.asabe.org/ abstract.asp?aid $=46786 \& \mathrm{t}=5$

Shamshiri R.R., Mahadi M.R., Thorp K.R., Ismail W.I.W., Ahmad D., and Man H.C., 2017a. Adaptive Management framework for evaluating and adjusting microclimate parameters in tropical greenhouse crop production systems. In: Plant Engineering (Ed. S. Jurić). Rijeka: InTech., http:// dx.doi. org/10.5772/intechopen.69972

Shamshiri R., Che Man H., Zakaria A.J., Beveren P.V., Wan Ismail W.I., and Ahmad D., 2017b. Membership function model for defining optimality of vapor pressure deficit in closed-field cultivation of tomato. Acta Horticulturae. Int. Soci. Hort. Sci. (ISHS), Leuven, Belgium, 281-290, https:// doi.org/10.17660/ActaHortic.2017.1152.38 
Shamshiri R., van Beveren P., Che Man H., and Zakaria A.J., 2017c. Dynamic assessment of air temperature for tomato (Lycopersicon esculentum Mill.) cultivation in a naturally ventilated net-screen greenhouse under tropical lowlands climate. J. Agric. Sci. Technol., 19(1), 59-72.

Shamshiri R., Ismail W.I.W., and Ahmad D., 2014. Experimental evaluation of air temperature, relative humidity and vapor pressure deficit in tropical lowland plant production environments. Advances Environ. Biol., 8(22), 5-13.

Shishido Y. and Kumakura H., 1994. Effects of root temperature on photosynthesis, transpiration, translocation and distribution of 14C-photoassimilates and root respiration in tomato. J. Japanese Soc. Hort. Sci., 63(1), 81-89.

Short T.H., Draper C.M., and Donnell M.A., 2005. Web-based decision support system for hydroponic vegetable production. Acta Horticulturae, Int. Soc. Hort. Sci. (ISHS), Leuven, Belgium, 867-870, https://doi.org/10.17660/ ActaHortic.2005.691.107.

Schrevens E., Tenorio J., Cooman A., and Medina A., 2005. Simulation of greenhouse management for the cultivation of tomato in the high altitude tropics. Acta Hort., 691(2002), 75-82.

Stockle C.O. and Kiniry J.R., 1990. Variability in crop radiation-use efficiency associated with vapor-pressure deficit. Field Crops Res., 25(3-4), 171-181.

Tindall J.A., Mills H.A., and Radcliffe D.E., 1990. The effect of root zone temperature on nutrient uptake of tomato. J. Plant Nutrition, 13(8), 939-956, https://doi.org/10.1080/ 01904169009364127

Triguii M., Barringtoni S.F., and Gauthier L., 1999. Effects of humidity on tomato. Canadian Agricultural Eng., 41(3), 135-140.

Van Ploeg D. and Heuvelink E., 2005. Influence of sub-optimal temperature on tomato growth and yield: a review. J. Hort. Sci. Biotechnol., 80(6), 652-659, https://doi.org/10.1080/14 620316.2005 .11511994
Vanthoor B.H.E., Stanghellini C., Van Henten E.J., and De Visser P.H.B., 2011. A methodology for model-based greenhouse design: Part 1, a greenhouse climate model for a broad range of designs and climates. Biosystems Eng., 110(4), 363-377, http://dx.doi.org/10.1016/j.biosystems eng.2011.06.001

Vermeulen K., Aerts J.-M., Dekock J., Bleyaert P., Berckmans D., and Steppe K., 2012. Automated leaf temperature monitoring of glasshouse tomato plants by using a leaf energy balance model. Computers and Electronics in Agriculture, 87, 19-31, http://dx.doi.org/10.1016/j.compag.2012.05.003

Viuda-Martos M., Sanchez-Zapata E., Sayas-Barberá E., Sendra E., Perez-Alvarez J.A., and Fernández-López J., 2014. Tomato and tomato byproducts. Human health benefits of lycopene and its application to meat products: a review. Critical reviews in food science and nutrition, 54(8), 1032-1049, http://www.ncbi.nlm. nih.gov/pubmed/ 24499120

Vogelezang J.V.M., 1993. Bench heating for potplant cultivation: analysis of effects of root-and air temperature on growth, development and production. Ph.D. Thesis, Wageningen Agricultural University, Wageningen, the Netherland.

Xu J., Li Y., Wang R.Z., Liu W., and Zhou P., 2015. Experimental performance of evaporative cooling pad systems in greenhouses in humid subtropical climates. Applied Energy, 138, 291-301,http://linkinghub.elsevier.com/retrieve/pii/ S0306261914011118

Zhang D., Zhongdian Z., Jianming L., Yibo C., Qingjie D., and Tonghua P., 2015. Regulation of vapor pressure deficit by greenhouse micro-fog systems improved growth and productivity of tomato via enhancing photosynthesis during summer season. PloS one, 10(7), p.e0133919.

Zolnier S., Gates R.S., Buxton J., and Mach C., 2000. Psychrometric and ventilation constraints for vapor pressure deficit control. Computers and Electronics in Agriculture, 26(3), 343-359. 